\title{
THE IMPACT OF VISIONARY LEADERSHIP IN ACHIEVING ORGANIZATIONAL HAPPINESS IN GOVERNMENT MINISTRIES IN THE STATE OF KUWAIT
}

\author{
Dr. Abdulmohsen Salem AlAjami \\ mo7sen82@hotmail.com
}

\begin{abstract}
:
This study aimed to know the impact of visionary leadership in achieving organizational happiness in Kuwaiti ministries. This study is considered as a descriptive and analytical study. A Convenience sample of (300) employees and administrators was selected to distribute the questionnaires on them and 233 questionnaires were returned. Thus, the response rate was (77.66\%). The researcher concluded that the relative importance of visionary leadership is high and that the (conservative leadership) dimension came in first place, while it came after (Vigorous leadership) in the last place with a high relative importance. This reflects the interest of the ministries under study in applying the dimensions of visionary leadership. It also showed the high level of organizational happiness among workers in Kuwaiti ministries.
\end{abstract}

Keywords:

Visionary Leadership, Organizational Happiness, State of Kuwait

Article Received: 18 October 2020, Revised: 3 November 2020, Accepted: 24 December 2020

\section{Introduction}

The changes we are witnessing in the business sector, the human factor within organizations and the current rapid innovations have made the concept of leadership very important and the need for managers who excel in leadership has increased. Organizational happiness is the most important cornerstone of organizations. Leadership and organizational happiness are the most important actors of organizational management. Also, no one can deny the important role that the positive or negative characteristics of the manager play on the psychology of the employees and the desire to work for them. Leaders must help organizations develop a greater sense of goal achievement by linking efforts to achieve successful outcomes. Visionary leadership provides opportunities to enhance an organization's ability to meet the needs of its departments. Visionary leaders develop their own personal vision and then combine it with a shared vision of their peers, and the literature has largely lacked an examination of the extent to which visionary leadership behaviors can actually produce changes in organizational happiness. (Granit ,2012)
The human resource is one of the most valuable resources of business organizations for its contribution to achieving their success, raising their efficiency, and their growth. In addition, it is the most complex resource among all other resources due to its exposure to internal or external environmental influences, and the study of human behavior has attracted the interest of many researchers, since the attention to employee behavior and attitudes will contribute in one way or another to improving his performance, and this in turn requires leadership that can direct This human resource is in the interest of the organization. What here emerges is the importance of the study from the subject of the study, which reviews a pattern of leadership, which is visionary leadership, where visionary leaders offer behaviors necessary for the followers themselves in order to obtain the knowledge, skills and abilities necessary to accomplish their work, so this study works on Adding information to literature related to this field and filling the research deficiency in this field, which gives great importance to this study.

Due to the importance of this government sector in the State of Kuwait, this study came to identify 
the impact of visionary leadership in achieving organizational happiness in Kuwaiti ministries .

Objectives of the study

The objectives of the study are the following:

1- Studying the impact of visionary leadership in achieving organizational happiness in government ministries in the State of Kuwait

2- Studying the influence of the conservative leadership in achieving organizational happiness in government ministries in the State of Kuwait.

3- Studying the impact of calculated leadership in achieving organizational happiness in government ministries in the State of Kuwait

4- Studying the influence of Vigorous leadership in achieving organizational happiness in government ministries in the State of Kuwait.

\section{Problem of The Study}

Today's organizations are facing rapid developments and changes in various fields, and they have had to adapt and adapt to them in order for them to succeed and continue, and the problem of the study revolves around the existence of difficulties for many organizations in benefiting from the application of the concept of visionary leadership in various fields, since this type of leadership is important Great in creating high levels of cohesion, commitment, confidence, motivation, and improving performance of workers in organizations .. These visionary leaders have an important role in activating organizational happiness and they must participate in the organization to create and sustain excellence upon preparation and lead the way to success.

Based on the above, the study problem can be crystallized in answering the following main question: Is there an effect of visionary leadership in achieving organizational happiness in government ministries in the State of Kuwait, answering this question in the following subquestions:

1- What is the impact of visionary leadership in achieving organizational happiness in government ministries in the State of Kuwait?
2- What is the influence of the conservative leadership in achieving organizational happiness in government ministries in the State of Kuwait?

3-What is the impact of calculated leadership in achieving organizational happiness in government ministries in the State of Kuwait?

4- What is the impact of vigorous leadership in achieving organizational happiness in government ministries in the State of Kuwait?

\section{Literature review}

\section{Visionary Leadership}

Visionary leadership has emerged since 1990 as a matter of utmost importance for workers in various fields and a survey of the available management literature reveals the origin, importance, characteristics and process of visionary leadership. It is of utmost importance for corporate survival, success and growth in today's turbulent environment today. Leaders must help organizations develop a greater sense of goal achievement by linking efforts to achieve successful outcomes. Indeed, visionary leadership provides opportunities to enhance the organization's ability to meet the needs of its components, and this occurs in creative ways, despite complex and turbulent circumstances, by providing a framework that can become a touchstone for setting goals and setting priorities; Aligning structures, policies, and beliefs with principles; And evaluation of progress. And visionary leaders, unlike transformational leaders, use vision based on their work. Visionary leadership has been defined as the ability to create and articulate clear, meaningful and purposeful visions for the work of an organization (Taylor Colette M. \& Casey J. Cornelius \& Kate Colvin, 2014). Visionary leaders develop their personal vision and then combine it with a shared vision of their colleagues. Tellis (2006) has emphasized that visionary leadership is a major factor in corporate success and failure.

It is said that visionary leadership stands apart from the other form of leadership in an inspiring vision and communicates that vision among subordinates so that organizations move from good to better (Jul-Chan \& Colin, 2004). 
Visionary leadership highlights positive results in organizations by creating and communicating a desired state view of affairs that clarifies the current situation and drives commitment to a better future. This leads to high leader confidence, high leader commitment, high levels of performance among employees, and high organizational performance. Visionary leaders also have insight into the needs or values of employees and develop a vision statement that reflects those needs or values (Kirkpatrick, 2004). This great leadership visionary concern about followers increases job satisfaction among workers in organizations (Lee, U. H., Kim, H. K. \& Kim, Y. H, 2013).

However, according to Sashkin \& Sashkin (2002), visionary leaders exhibit behaviors (i.e. confidence, pro-social power behaviors, and organizational capabilities) that are essential to employees themselves in order to acquire knowledge, skills, and abilities to achieve organizational goals. In addition, visionary leadership theory provides an understanding of an individual's leadership style as it relates to the organizational context and effectiveness. Researchers examined exceptional leaders or "visionary men" who were responsible for a tangible growth in the success of their organizations. It was found that leaders are highly respected and viewed as having the ability to express visions or tasks to their followers, and then inspire and empower those followers to participate and generate returns by creating Change in organizational function and growth. And visionary leadership: Zhu, W., Chew, I.K.H. and Spangler, W.D. (2005)) create high levels of cohesion, commitment, confidence, motivation, and performance improvement in new organizations. Where the influence of leader effectiveness can be used to measure organizational effectiveness (Hogan \& Kais 2005). A visionary leader understands the external environment, responds appropriately, and has an important role in shaping and influencing organizational practices, procedures, products and services. This type of leader has an important role in activating the vision. Organizational and they must be involved in the organization to bring about and sustain excellence when prepared and lead the way to success. Therefore, they in positions of authority will need a better understanding of leadership, organizational change, and effectiveness (Taylor et al, 2014).

The following are the dimensions of visionary leadership:

\section{- Conservative Leadership}

It is a means by which the legitimacy of the organization is diminished and thus the power it is required to develop and develop. Conservative leadership tries to overlook changes and thus keep the core of the organization intact. (Taylor \& De Lourdes Machado, 2006)

\section{- Calculated Leadership}

Almog-Bareket (2012) argues that calculated leadership has adopted institutional elements that are well recognized by the environment, so that the organization can maintain its legitimacy. Given the intense competition, organizations are often reluctant to adopt an organizational model that focuses on achieving a unique identity and competitive advantage, rather than adopting a global model, because they fear bearing losses as a result of change.

\section{- Vigorous Leadership}

Vigorous leadership is based on a number of principles, the most important of which is influencing situations. Individuals are the ones who make these decisions themselves and bring their positions with them to work every day (Oh and Kuchinke, 2017).

\section{Organizational Happiness}

The word happiness has appeared in the literature with multiple names, including permanent happiness, positive impact feature, or selfhappiness. During this study we will use the term organizational happiness that occurs within the workplace because it is the focus of the study. Workplace plays a decisive role in the happiness of people. If there is any hope for people to find general happiness in their daily lives, then they should find that. Happiness in the workplace. Although work by itself, it cannot make a person 
happy, a person cannot be truly happy if he is unhappy at work. Therefore, encouraging the psychological happiness of leaders and workers is a good thing in itself, and it is also a good way to enhance individual and organizational performance.

Peyton and Patrica(2008) indicates that happy people are more benefiting from the opportunities available in their work environments, as well as more helpful to their co-workers, and more confident and optimistic. It indicates that unhappy people are less performing than happy people.

Based on studies conducted by (Baker et al., 2006) they indicated that happy organizations have the following:

1. The workers are more creative, and are able to make positive change.

2. He directs its workers to do (the best possible) and not just solve problems.

3. Encouraging team work and a positive vision.

4. Leaders work to create a work environment that enhances cooperation within the organization.

Dimensions Of Organizational Happiness In The Workplace

The dimensions of organizational happiness in the workplace in three dimensions, namely (positive emotional affect, negative emotional affect, and FULFILLMENT). These dimensions can be explained in detail as follows: -(Demo and Paschoal, 2013)

1- Positive Affect:

The emotional effect is known as "a wide range of feelings that face people." As for the positive emotional effect, it is (the emotions that come from pleasure, excitement and comfort, which represent the positive influences and indicate high happiness) (Demo and Paschoal, 2013), and Green(2014) argued that the positive effect is "the display of happy feelings that may lead to improved performance, such as joy, pleasure and pride, which are the opposite of negative influence and sad feelings."

2- Negative Affect:

Negative emotional impact can be defined as (the emotions that come from anxiety, depression, and resentment, which represent negative influences and indicate decreased happiness) (Paschoal, \& Demo, 2013: P4). Green( 2014,) believes that negative influences are "a set of behaviors that a worker uses to raise his or her private position at the expense of other workers, their beliefs, or their sense of self-worth, and that negative feelings result from the actions of others and reflect their desire to control To others, or to harm them. "

3- Fulfillment:

Fulfilment is the process of perception that relates to workers' development of their skills and potentials at work and progress in achieving their life goals-(Demo and Paschoal, 2013). Warr(2007) says that there is a continuous attempt by managers to attract and retain special skills at work, and that this lies by providing the necessary working conditions (such as happiness and satisfactory acceptance) in order to ensure their proper performance at work.

\section{Study Hypotheses:}

In light of the study problem and the questions raised in it, the study adopted the following hypotheses:

\section{Main Hypothesis:}

Ho: There is no statistically significant effect at the level of significance $(\alpha \leq 0.05)$ of visionary leadership with its combined dimensions in achieving organizational happiness in government ministries in the State of Kuwait.

It stems from the following sub-hypotheses:

Ho.1: There is no statistically significant effect at a significant level $(\alpha \leq 0.05)$ for conservative leadership in achieving organizational happiness in government ministries in the State of Kuwait.

Ho.2: There is no statistically significant effect at the level of significance $(\alpha \leq 0.05)$ of the calculated leadership in achieving organizational happiness in government ministries in the State of Kuwait.

Ho.3: There is no statistically significant effect at a significant level $(\alpha \leq 0.05)$ of vigorous leadership in achieving organizational happiness in government ministries in the State of Kuwait. 
The Study Model:

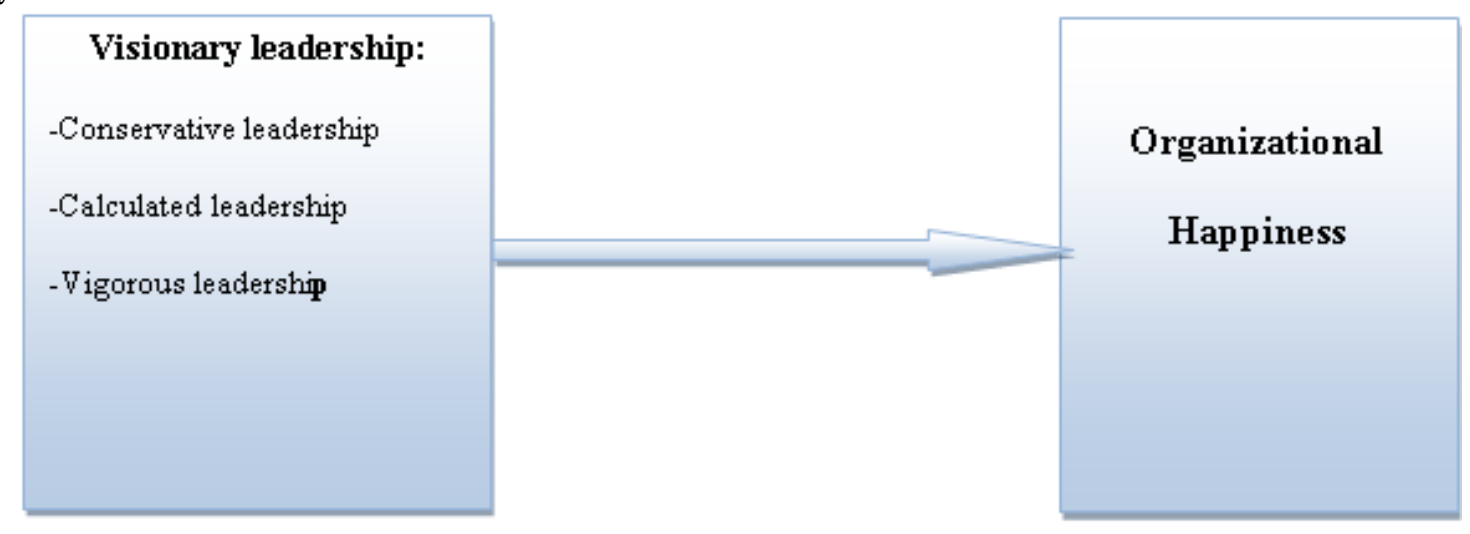

\section{Study methodology}

This study is considered as a descriptive and analytical study to identify the impact of wise leadership in achieving organizational happiness in government ministries in the State of Kuwait by reviewing the theoretical literature and previous studies related to the study variables and conducting the field study.

\section{Study Population And Sample}

The study population consists of workers in government ministries in the State of Kuwait. A Convenience sample of (300) employees and administrators was selected to distribute the questionnaires on them and 233 questionnaires were returned. Thus, the response rate was $(77.66 \%)$

\section{Sources Of Data Collection :}

Primary Data:

It was collected through the questionnaire of the study that will be prepared to achieve the objectives of the study and test its hypotheses.

\section{Secondary Data}

Secondary data sources were referenced from books, references, periodicals, magazines and studies.

\section{Statistical Analysis \\ Sample Characteristics}

It is found that the majority of the sample was males forming $77.3 \%$ of the sample compared to females forming only $22.7 \%$ of the sample.Also, it is appeared that the majority of the sample was individuals within the age range of 31-36 years old forming $37.5 \%$ of the sample compared to individuals within the age range of 25-30 years old forming only $14.1 \%$ of the sample .As well as, the majority of the sample was individuals holding the bachelor degree forming $71.9 \%$ of the sample compared to those who held the master degree forming $12.9 \%$. According to experience, it indicated that $44.5 \%$ of the sample has $7-11$ years of experience

\section{Descriptive Analysis}

Mean and standard deviation were used to describe attitudes toward the following variables:

\begin{tabular}{|c|c|c|c|c|c|}
\hline \multicolumn{7}{|c|}{ Table (1) Descriptive Statistics } \\
\hline & $\mathrm{N}$ & $\begin{array}{c}\text { Minimu } \\
\mathrm{m}\end{array}$ & $\begin{array}{c}\text { Maximu } \\
\mathrm{m}\end{array}$ & Mean & $\begin{array}{c}\text { Std. } \\
\text { Deviation }\end{array}$ \\
\hline Conservative leadership & 233 & 1.00 & 5.00 & 4.1124 & .81170 \\
\hline Calculated leadership & 233 & 1.00 & 5.00 & 3.8790 & .91592 \\
\hline Vigorous leadership & 233 & 1.00 & 5.00 & 3.8335 & .97153 \\
\hline Organizational Happiness & 233 & 1.00 & 5.00 & 4.5974 & .72528 \\
\hline
\end{tabular}

Above table shows that there are positive attitudes toward above variables because their means are above mean of the scale (3). also it is found that Conservative leadership is the most dimension of visionary leadership that is applied in Kuwaiti ministries.

\section{Reliability Test}


Cronbach's alpha was used for the reliability test. it resulted in a value of (0.924) for all the items within the study, the alpha however resulted greater than 0.60 which indicated the tool consistency that enhanced its use in the study Hypothesis Testing
Ho: There is no statistically significant effect at the level of significance $(\alpha \leq 0.05)$ of visionary leadership with its combined dimensions in achieving organizational happiness in government ministries in the State of Kuwait.

\begin{tabular}{|l|l|c|c|c|}
\hline \multicolumn{5}{|c|}{ Table (2) Ho analysis } \\
\hline Model & $\mathrm{R}$ & R Square & $\begin{array}{c}\text { Adjusted R } \\
\text { Square }\end{array}$ & $\begin{array}{c}\text { Std. Error of the } \\
\text { Estimate }\end{array}$ \\
\hline 1 & .718 & .516 & .509 & .50812 \\
\hline
\end{tabular}

\begin{tabular}{|c|c|c|c|c|c|c|c|}
\hline \multicolumn{8}{|c|}{ ANOVA } \\
\hline & Model & \multirow{2}{*}{\multicolumn{2}{|c|}{$\begin{array}{c}\text { Sum of Squares } \\
62.913\end{array}$}} & \multirow{2}{*}{$\frac{\mathrm{df}}{3}$} & \multirow{2}{*}{\begin{tabular}{c|} 
Mean Square \\
20.971
\end{tabular}} & \multirow{2}{*}{$\frac{F}{81.224}$} & \multirow{2}{*}{$\begin{array}{l}\text { Sig. } \\
.000\end{array}$} \\
\hline \multirow[t]{3}{*}{1} & Regression & & & & & & \\
\hline & Residual & \multicolumn{2}{|c|}{59.125} & 229 & .258 & & \\
\hline & Total & \multicolumn{2}{|c|}{122.038} & \multicolumn{2}{|l|}{232} & & \\
\hline & & & & & & & \\
\hline \multicolumn{8}{|c|}{ Coefficients } \\
\hline \multirow{2}{*}{\multicolumn{2}{|c|}{ Model }} & \multicolumn{3}{|c|}{$\begin{array}{l}\text { Unstandardized } \\
\text { Coefficients }\end{array}$} & $\begin{array}{c}\text { Standardized } \\
\text { Coefficients }\end{array}$ & \multirow[b]{2}{*}{$\mathrm{t}$} & \multirow[b]{2}{*}{ Sig. } \\
\hline & & B & Std & Error & Beta & & \\
\hline \multirow[t]{4}{*}{1} & (Constant) & 1.945 & & 175 & & 11.110 & .000 \\
\hline & $\begin{array}{c}\text { Conservative } \\
\text { leadership }\end{array}$ & .657 & & 995 & .736 & 6.899 & .000 \\
\hline & $\begin{array}{l}\text { Calculated } \\
\text { leadership }\end{array}$ & .076 & & 122 & .096 & .618 & .537 \\
\hline & $\begin{array}{l}\text { Vigorous } \\
\text { leadership }\end{array}$ & -.090 & & 102 & -.121 & -.881 & .379 \\
\hline
\end{tabular}

Above hypothesis was tested using Multiple regression analysis which scored an $\mathrm{R}$ value of 0.718 and an $F$ value of 81.224 is significant at (0.05). This confirmed that independent variables and dependent variable are correlated and that means There is statistically significant effect at the level of significance $(\alpha \leq 0.05)$ of visionary leadership with its combined dimensions in achieving organizational happiness in government ministries in the State of Kuwait

It stems from the following sub-hypotheses:

Ho.1: There is no statistically significant effect at a significant level $(\alpha \leq 0.05)$ for conservative leadership in achieving organizational happiness in government ministries in the State of

\begin{tabular}{|c|c|c|c|c|}
\hline \multicolumn{5}{|c|}{ Table (3) Ho1 analysis } \\
\hline Model & R & R Square & $\begin{array}{c}\text { Adjusted R } \\
\text { Square }\end{array}$ & $\begin{array}{c}\text { Std. Error of } \\
\text { the Estimate }\end{array}$ \\
\hline 1 & .717 & .514 & .512 & .50678 \\
\hline
\end{tabular}




\begin{tabular}{|c|c|c|c|c|c|c|}
\hline \multicolumn{7}{|c|}{ ANOVA } \\
\hline \multicolumn{2}{|c|}{ Model } & $\begin{array}{l}\text { Sum of } \\
\text { Squares }\end{array}$ & df & Mean Square & $\mathrm{F}$ & Sig. \\
\hline \multirow[t]{3}{*}{1} & Regression & 62.713 & 1 & 62.713 & 244.187 & .000 \\
\hline & Residual & 59.326 & 231 & .257 & & \\
\hline & Total & 122.038 & 232 & & & \\
\hline \multicolumn{7}{|c|}{ Coefficients } \\
\hline \multirow{2}{*}{\multicolumn{2}{|c|}{ Model }} & \multicolumn{2}{|c|}{$\begin{array}{l}\text { Unstandardized } \\
\text { Coefficients }\end{array}$} & $\begin{array}{l}\text { Standardized } \\
\text { Coefficients }\end{array}$ & & \\
\hline & & $\mathrm{B}$ & Std. Error & Beta & $\mathrm{t}$ & Sig. \\
\hline \multirow[t]{2}{*}{1} & (Constant) & 1.963 & .172 & & 11.427 & .000 \\
\hline & $\begin{array}{c}\text { Conservative } \\
\text { leadership }\end{array}$ & .641 & .041 & .717 & 15.626 & .000 \\
\hline
\end{tabular}

Above hypothesis was tested using linear regression analysis which scored an $\mathrm{R}$ value of 0.717 and $t$ value of 15.626 is significant at (0.05). This confirmed that independent variable and dependent variables are correlated and that means there is statistically significant effect at a significant level $(\alpha \leq 0.05)$ for conservative leadership in achieving organizational happiness in government ministries in the State of Kuwait.

Ho.2: There is no statistically significant effect at the level of significance $(\alpha \leq 0.05)$ of the calculated leadership in achieving organizational happiness in government ministries in the State of Kuwait.

\begin{tabular}{|c|c|c|c|c|c|c|}
\hline \multicolumn{5}{|c|}{ Table (4) Ho2 analysis } & & \\
\hline Model & $\mathrm{R}$ & R Square & $\begin{array}{l}\text { Adjusted R } \\
\text { Square }\end{array}$ & $\begin{array}{l}\text { Std. Error of } \\
\text { the Estimate }\end{array}$ & & \\
\hline 1 & .644 & .415 & .412 & .55607 & & \\
\hline \multicolumn{7}{|c|}{ ANOVA } \\
\hline \multicolumn{2}{|c|}{ Model } & $\begin{array}{l}\text { Sum o } \\
\text { Square }\end{array}$ & f & Mean Square & $\mathrm{F}$ & Sig. \\
\hline \multirow[t]{3}{*}{1} & Regression & 50.610 & 1 & 50.610 & 163.672 & .000 \\
\hline & Residual & 71.429 & 231 & .309 & & \\
\hline & Total & 122.038 & 232 & & & \\
\hline \multicolumn{7}{|c|}{ Coefficients } \\
\hline \multirow{2}{*}{\multicolumn{2}{|c|}{ Model }} & \multicolumn{2}{|c|}{$\begin{array}{l}\text { Unstandardized } \\
\text { Coefficients }\end{array}$} & $\begin{array}{l}\text { Standardized } \\
\text { Coefficients }\end{array}$ & & \\
\hline & & B & Std. Error & Beta & $\mathrm{t}$ & Sig. \\
\hline \multirow[t]{2}{*}{1} & (Constant) & 2.619 & .159 & & 16.490 & .000 \\
\hline & $\begin{array}{l}\text { Calculated } \\
\text { leadership }\end{array}$ & .510 & .040 & .644 & 12.793 & .000 \\
\hline
\end{tabular}

Above hypothesis was tested using linear regression analysis which scored an $\mathrm{R}$ value of 0.644 and $t$ value of 12.793 is significant at $(0.05)$.
This confirmed that independent variable and dependent variables are correlated and that means there is statistically significant effect at the level 
of significance $(\alpha \leq 0.05)$ of the calculated leadership in achieving organizational happiness in government ministries in the State of Kuwait.

Ho.3: There is no statistically significant effect at a significant level $(\alpha \leq 0.05)$ of vigorous leadership in achieving organizational happiness in government ministries in the State of Kuwait.

\begin{tabular}{|c|c|c|c|c|c|c|}
\hline \multicolumn{5}{|c|}{ Model Summary } & & \\
\hline Model & $\mathrm{R}$ & R Square & $\begin{array}{l}\text { Adjusted R } \\
\text { Square }\end{array}$ & $\begin{array}{l}\text { Std. Error of } \\
\text { the Estimate }\end{array}$ & & \\
\hline 1 & $.609^{a}$ & .371 & .369 & .57629 & & \\
\hline \multicolumn{7}{|c|}{ ANOVA } \\
\hline \multicolumn{2}{|c|}{ Model } & $\begin{array}{l}\text { Sum of } \\
\text { Squares }\end{array}$ & f & Mean Square & $\mathrm{F}$ & Sig. \\
\hline \multirow[t]{3}{*}{1} & Regression & 45.320 & 1 & 45.320 & 136.460 & .000 \\
\hline & Residual & 76.718 & 231 & .332 & & \\
\hline & Total & 122.038 & 232 & & & \\
\hline \multicolumn{7}{|c|}{ Coefficients } \\
\hline \multirow{2}{*}{\multicolumn{2}{|c|}{ Model }} & \multicolumn{2}{|c|}{$\begin{array}{l}\text { Unstandardized } \\
\text { Coefficients }\end{array}$} & $\begin{array}{l}\text { Standardized } \\
\text { Coefficients }\end{array}$ & & \\
\hline & & B & \begin{tabular}{l|l} 
& Std. Error
\end{tabular} & Beta & $\mathrm{t}$ & Sig. \\
\hline \multirow[t]{2}{*}{1} & (Constant) & 2.853 & .154 & & 18.530 & .000 \\
\hline & $\begin{array}{l}\text { Vigorous } \\
\text { leadership }\end{array}$ & .455 & .039 & .609 & 11.682 & .000 \\
\hline
\end{tabular}

Above hypothesis was tested using linear regression analysis which scored an $\mathrm{R}$ value of 0.609 and $t$ value of 11.682 is significant at (0.05). This confirmed that independent variable and dependent variables are correlated and that means there is statistically significant effect at a significant level $(\alpha \leq 0.05)$ of vigorous leadership in achieving organizational happiness in government ministries in the State of Kuwait.

\section{Conclusion and Recommendations}

This study aimed to know the impact of visionary leadership in achieving organizational happiness in Kuwaiti ministries. The researcher concluded that the relative importance of visionary leadership is high and that the (conservative leadership) dimension came in first place, while it came after (Vigorous leadership) in the last place with a high relative importance. This reflects the interest of the ministries under study in applying the dimensions of visionary leadership. It also showed the high level of organizational happiness among workers in Kuwaiti ministries. It has been concluded that there is a statistically significant effect at the level of significance $(\alpha \leq 0.05)$ of visionary leadership with its combined dimensions in achieving organizational happiness in government ministries in the State of Kuwait. Also, there is statistically significant effect at a significant level $(\alpha \leq 0.05)$ for conservative leadership in achieving organizational happiness in government ministries in the State of Kuwait. As well as, there is statistically significant effect at the level of significance $(\alpha \leq 0.05)$ of the calculated leadership in achieving organizational happiness in government ministries in the State of Kuwait. And there is statistically significant effect at a significant level $(\alpha \leq 0.05)$ of vigorous leadership in achieving organizational happiness in government ministries in the State of Kuwait. Also, it is found that conservative leadership has the highest impact in achieving organizational happiness in Kuwaiti ministries. 
The researcher recommends the necessity of applying wise leadership in the ministries by holding specialized training courses in this field, and the necessity of the Kuwaiti ministries 'interest in achieving a high level of organizational happiness, and working to meet the needs of departments at different levels without delay in order to develop work in the organization and improve the level of service provided. And work to educate employees about the need to comply with orders at work, in order to enhance discipline at work. In addition to the need for senior management to encourage colleagues to perform the work of those who are absent from them, and to work to enhance altruistic behavior among the employees of the ministries in a way that contributes to improving the level of organizational happiness, and to conduct other studies on the subject of study by application to other economic sectors

\section{References}

[1] Baker, D.; Greenberg, C.; \& Hemingway, C. (2006): "What Happy Companies Know", Pearson Education. Nova Jersey, USA.

[2] Cropanzano, R. \& Wright, T. (2001). "When a "happy" worker is really a "productive" worker: A review and further refinement of the happy-productive worker thesis".Consulting Psychology Journal: Practice and Research, 53(3),182-199.

[3] Demo, G. \& Paschoal, Tatiane (2013), "WellBeing at Work Scale: Exploratory and Confirmatory Validation in the United States Comprising Affective and Cognitive Components", rio de janeiro.

[4] Granit, A. B. (2012). Visionary leadership in business schools: an institutional framework. Journal of Management Development, 31(4), $431-440$.

[5] Green, R. (2014), "Impact of Middle-Level Managers' Well-Being and Happiness on Direct Reports' Performance", Walden University.
[6] Hogan, R. \& Kaiser, R.B. (2005). "What we know about leadership". Review of General Psychology, 9 (2), 169-180.

[7] Kirkpatrick, S. A., (2004). Visionary leadership theory: encyclopedia of leadership. NY: SAGE publication .

[8] Lee, U. H., Kim, H. K. \& Kim, Y. H., (2013). Determinant of organizational citizenship behavior and its outcomes. Global Business and Management Research: An International Journal, 5(1), 54-65.

[9] Oh, S. and Kuchinke, K. (2017). Exploring the role of organizational learning activities in the quality management context. Leadership \& Organization Development Journal, 38(3), pp.380-397.

[10] Peyton \& Patricia, (2008), "Happiness at work as Described by Nurse mangers at Kelowna General Hospital", BSc in Nursing, University of Victoria, Canada.

[11] Sashkin, M. \& Sashkin, M.G. (2002). Leadership that Matters: The Critical Factors for Making a Difference in People's Lives and Organization's Success, Berrett-Koehler Publishers Inc., San Francisco, CA.

[12] Taylor Colette M. \& Casey J. Cornelius \& Kate Colvin , (2014). Visionary leadership and its relationship to organizational effectiveness. Leadership \& Organization Development Journal, 35 (6), 566 - 583. Permanent link to this document: http://dx.doi.org/10.1108/LODJ-10-20120130.

[13] Tellis, G.J. (2006). Disruptive Technology or Visionary Leadership?, Journal of Product Innovation Management, 23, 34-38.

[14] Warr, P. (2007). "Work, happiness and unhappiness". New Jersey: Lawrence Erlbaum Associates.

[15] Zhu, W., Chew, I.K.H. \& Spangler, W.D. (2005). CEO transformational leadership and organizational outcomes: the mediating role of human-capital-enhancing human resource management. The Leadership Quarterly, 16 (1), 39-52. 